ppi $201502 Z U 4645$

Esta publicación científica en formato digital es continuidad de la revista impresa ISSN-Versión Impresa 0798-1406 / ISSN-Versión on line 2542-3185Depósito legal pp $197402 Z$ U34

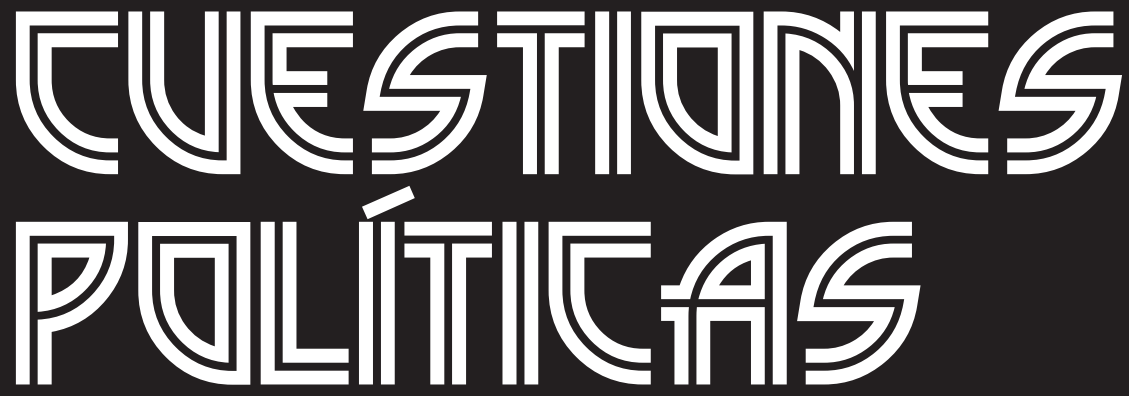

Instituto de Estudios Políticos y Derecho Público "Dr. Humberto J. La Roche" de la Facultad de Ciencias Jurídicas y Políticas de la Universidad del Zulia Maracaibo, Venezuela
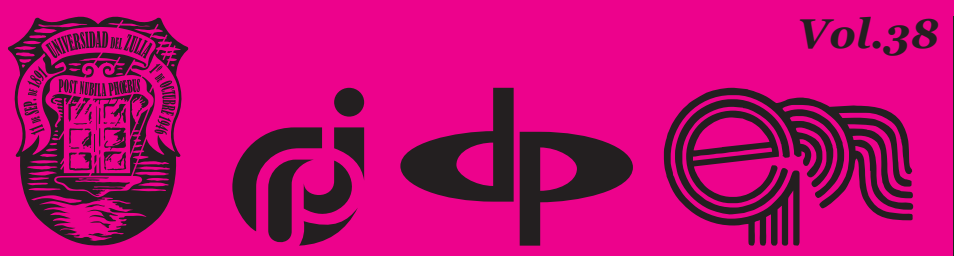

$N^{\circ}$ Especial 1era Parte 2020 


\title{
Official work in Ukraine: characteristics of legal status and recurring problems
}

\author{
DOI: https://doi.org/10.46398/cuestpol.38e.22
}

\author{
Mykhailo Pokalchuk * \\ Kateryna Sokh \\ Oksana Yalova *** \\ Liuboy Zubkova ${ }^{* * * *}$ \\ Iryna Borovska ${ }^{* * * * *}$
}

\begin{abstract}
The purpose of the article is to analyze the concept of «contract work» in Ukrainian legislation, determine its characteristics, as well as identify the scope of rights that arise with its creation. The methodological basis of the research is a series of general and special scientific methods of cognition. In the research process, formal and logical methods, systems and structural, comparative and legal, logical and legal and other scientific research methods were used. The rules of Ukrainian legislation, which regulate the subject under consideration, were investigated; they were compared with the relevant laws of some states of the world. Judicial practice, which deals with some problems related to the distribution of contract work rights between an employer and an employee, was also examined. Practical implication. The concept of «paid work» in the Ukrainian legislation was analyzed, its characteristics were identified, which are at the same time the conditions for recognizing work as paid work. By way of conclusion, it is convenient to distinguish the non-patrimonial and property rights of an employer and employee to work under contract, which in turn implies the problem of
\end{abstract} determining the amount of royalties.

* PhD in Law, Professor, Assistant of the Department of Land and Agrarian Law of Yaroslav Mudryi National Law University, Ukraine. ORCID ID: https://orcid.org/oooo-0001-9622-9114. Email: kancel@nulau.edu.ua

** PhD in Law, Senior Lecturer of the Department of Constitutional Law and Human Rights of the National Academy of Internal Affairs, Ukraine. ORCID ID: https://orcid.org/oooo-0002-5538-2566. Email: post@naiau.kiev.ua.

*** PhD in Law, Associate Professor of the Department of Legal Documentation of the National Academy of Internal Affairs, Ukraine. ORCID ID: https://orcid.org/oooo-0002-0813-5327. Email: post@naiau. kiev.ua).

*** PhD in Law, Senior Researcher of the Secretariat of the Academic Council of the National Academy of Internal Affairs, Ukraine. ORCID ID: https://orcid.org/oooo-0oo3-3090-912X. Email: post@naiau. kiev.ua).

*****PhD in Law, Associate Professor of the Department of Civil Law and Procedure of the National Academy of Internal Affairs, Ukraine. ORCID ID: https://orcid.org/oooo-0002-4961-9707. Email: post@naiau.kiev.ua). 
Keywords: contract work; rights not related to property; property rights; labor rights; legal status.

\section{Trabajo oficial en Ucrania: características del estatus legal y problemas recurrentes}

\section{Resumen}

El objetivo del artículo es analizar el concepto de «trabajo por contrato» en la legislación ucraniana, determinar sus características, así como identificar el alcance de los derechos que surgen con su creación. La base metodológica de la investigación es una serie de métodos científicos generales y especiales de cognición. En el proceso de investigación se utilizaron métodos formales y lógicos, sistemas y métodos estructurales, comparativos y legales, lógicos y legales y otros de investigación científica. Se investigaron las reglas de la legislación ucraniana, que regulan el tema en consideración; fueron comparados con las leyes relevantes de algunos Estados del mundo. También se examinó la práctica judicial, que se ocupa de algunos problemas relacionados con la distribución de derechos al trabajo por contrato entre un empleador y un empleado. Implicación práctica. Se analizó el concepto de «trabajo a sueldo» en la legislación ucraniana, se identificaron sus características, que son al mismo tiempo las condiciones para reconocer el trabajo como trabajo a sueldo. A modo de conclusión conviene distinguir los derechos no patrimoniales y de propiedad de un empleador y empleado para trabajar por contrato, lo implica a su vez el problema de la determinación de la cantidad de regalías.

Palabras clave: trabajo por contrato; derechos no relacionados con la propiedad; derechos de propiedad; derechos laborales; estatus legal.

\section{Introduction}

It is well known that every person has the right to own, use and dispose of the results of their intellectual, creative activities, other objects of intellectual property rights. Intellectual property rights are divided into property rights in intellectual property law and non-property rights in intellectual property law. However, a significant number of intellectual property rights are created by employees in the performance of their duties. These are, first of all, employees of creative and intellectual professions, who create works of science, literature and art in the course of their official duties. For example, scientific and pedagogical workers are also obliged to 
prepare methodological, didactic and educational materials for organizing relevant scientific and practical classes in addition to performing their direct work duties (conducting lectures, seminars and workshops). Therefore, in carrying out such activities, the employee produces a work-for-hire, the legal status of which requires additional clarification and regulation.

The most complex and relevant is the issue of the amount of payment to which the author of this kind of work is entitled, and which are established by the employment contract and (or) civil contract between the author and the employer. Secondly, the Civil Code of Ukraine (2003) stipulates that intellectual property rights to an object created in connection with the performance of an employment contract belong to the employee, who created the object, and to the legal person or to the individual, in which or for which he (she) works, jointly, which, however, does not mean equally. Therefore, it is important to determine which part of the property rights to the work-for-hire belongs to the employee, and which one - to the employer.

The problems associated with the distribution of rights to the work are mainly related to the dual legal regulation of these relations. Thus, the legislation of Ukraine stipulates that the issue of the exclusive property right to a work-for-hire may be regulated by an employment contract (contract) and (or) a civil contract between the author and the employer. It is the misunderstanding of the subject matter of legal regulation that leads to conflict situations between these persons. It is these and other problems related to the legal status of the work-for-hire, which led to the need for this study.

\section{Methodology}

The methodological basis of the research is a number of general scientific and special methods of cognition, the choice of which is determined by the features of its object, subject, purpose and tasks. In the process of research formal and logical method, system and structural, comparative and legal, logical and legal and other methods of scientific research were used.

The analysis of the achievements of civil law, the norms of current legislation of Ukraine and some other countries and the practice of their application in the area of copyright protection in legal relations related to the creation of a work-for-hire, was conducted using the formal and logical method.

The system and structural method was applied to clarify the system of methods and means of protection of rights to a work-for-hire, their relationship with the general means of protection of civil rights provided by the current legislation of Ukraine. 
The legal regulation of relations arising in connection with the creation of work-for-hire, as well as the ways to protect the rights to it under the laws of other countries were studied with the help of comparative and legal method.

The methods of analysis and generalization were applied in the course of case law study.

The main conclusions of the Article are based on the analysis of international acts on protection the rights to work-for-hire, current legislation of Ukraine and foreign legislation, practice of their application, achievements of general theory of civil law, intellectual property law, case law materials.

\section{Literature Review}

A number of foreign and Ukrainian scientists have considered the problems, connected with the copyright in general and work-for-hire in particular. For example, Matthew R. Harris (1990) studied the doctrines of Copyright, Computer Software, and Work Made for Hire. He examined, inter alia, what can be considered work-for-hire, and what cannot be considered as such; investigated the court practice concerning the settlement of disputes between the employers and the authors of the works; researched the history of establishment of work-for-hire doctrine and the development of legislative regulation of the issues related to this legal institution.

The representatives of the Sutherland Asbill \& Brennan LLP (2004) conducted a comprehensive analysis of international work-for-hire laws. They studied the legislation concerning the issue under consideration of such States as USA, Australia, the UK, France, Germany, China, Japan. As the result the authors come to the conclusion that the overall approach to such works is rather similar in all the countries under consideration. All six countries acknowledge at least on a limited basis copyright in an employer when the employee creates the work within the scope of his employment.

Jon M. Garon and Elaine Ziff (2011) examined the US copyright law in general and the rules regulating the legal regime of the work-for-hire in particular. They provided us with the inclusive case law study, in the course of studying of which they considered a lot of illustrative court decisions such as JustMed, Inc. v. Byce, Woods v. Resnick, Mattel, Inc. v. MGA Entertainment, Inc, Marshall v. Miles Laboratories, etc. The researches state that most business works are created as works made for hire, which vests the copyright in the employer rather than the employee. If the employer and employee cannot reach agreement between themselves, than the work for hire doctrine will be used for regulating relations between them. 
Mykhailo Pokalchuk, Kateryna Sokh, Oksana Yalova, Liubov Zubkova y Iryna Borovska 346

Official work in Ukraine: characteristics of legal status and recurring problems

Among Ukrainian scientists this problem was studied by Kulbashna (2013), Denisova (2011), Soloviova (2008), Potomkin (2007) and others.

\section{Results and Discussions}

\subsection{The concept of "work-for-hire" and its features}

The Civil Code of Ukraine (2003) does not provide for the concept of "work-for-hire", but uses the phrase "object created in connection with the performance of an employment contract". The definition of "work-for-hire" is enshrined in the Law of Ukraine "On Copyright and Related Rights" (1993), according to which it is a work created by the author in the performance of the official (work) duties in accordance with the employment contract (her) between him and the employer (Art. 1).

Thus, an official work is a work created:

- by the author (employee) when performing his (her) official (work) duties.

- in accordance with the duty assignment or employment contract between the author (employee) and the employer.

The Law of Ukraine "On Copyright and Related Rights" (Art. 8) establishes the list of objects of copyright in the area of science, literature and art (i.e. those that, in particular, can be works-for-hire): literary written works of fiction, journalistic, scientific, technical or other nature (books, brochures, articles, etc.); speeches, lectures, sermons and other oral works; computer programs; databases; audiovisual works; works of fine art; works of architecture, urban planning and landscape art; photographic works, including works made in a manner similar to photography; illustrations, maps, plans, drawings, sketches, plastic works related to geography, geology, topography, technology, architecture and other areas of activity; collections of works, collections of folklore, encyclopedias and anthologies, collections of ordinary data, other compiled works, provided that they are the result of creative work on the selection, coordination or organization of content without infringing copyright on the works that are part of them; other works.

The analysis of the aforementioned rules allows to identify the following features of the official work, which are also conditions for recognition of the work as work-for-hire:

1) the author is in an employment relationship with the employer on the basis of an employment contract; 
2) the work must be created by the author in the course of performance of his (her) official (work) duties, i.e. the obligation to create worksfor-hire is part of the official (work) duties of the employee;

3) the work should be created in accordance with the duty assignment or employment contract between the author and the employer. In this case, as Kulbashna (2013) correctly points out, the very fact of hiring an employee and concluding an employment contract is not sufficient enough for the employer to obtain all or part of the intellectual property rights to works created by the employee during the performance of his (her) duties. The employer can acquire the rights only to those works-for-hire, for the performance of which the employee has received a duty assignment or which were clearly specified in the employment contract. The official task can be expressed in the form of an order or a separate official note. It can be formalized as an agreement on the creation of a work-for-hire, in which it is necessary to specify: a) the subject of the agreement (object of copyright); b) the terms of its execution; c) the amount of remuneration for the creation of the copyright object.

4) the creation of work-for-hire can be carried out both during working hours and after work hours, regardless of the place of its creation; both with the use of means and materials belonging to the employer, and without such means and materials.

5) the object should be recognized as official, if the employer provided its creator with the necessary financial, material or other assistance or otherwise contributed to it in the process of creating the specified object. It can be enshrined in the employment contract that the material and technical base of the employer (equipment, software, etc.) is prohibited to be used for the creation of works, intellectual property rights to which do not belong to the latter. The completion of the copyright object is fixed by an acceptance certificate, so that in case of conflict such a work could be identified (Denisova, 2011).

However, as Soloviova (2008: p.35) notes in this regard, "fixing in special laws on certain types of intellectual property rights the list of conditions necessary for their classification as official limits the possibility of recognizing all, without exception, intellectual property rights that may be created by an employee as a result of performance of the employment contract and allows to classify as works-for-hire only those, which are created not simply as a result of performance of the employment contract, but as a result of performance of official duties under the employment contract or the assigned duty".

Such an opinion is entitled to be expressed, because, for example, the Law of Ukraine "On protection of rights to inventions and utility models" 

Mykhailo Pokalchuk, Kateryna Sokh, Oksana Yalova, Liubov Zubkova y Iryna Borovska 348
Official work in Ukraine: characteristics of legal status and recurring problems

(1994) stipulates that the invention is work-for-hire created by an employee using experience, production knowledge, production secrets and employer equipment. However, it is not clear from the content of this article whether all these conditions must be met for the invention to be considered workfor-hire, or whether the existence of one of them is sufficient enough.

Thus, we have defined what is meant by the term "work-for-hire" and defined its features. Now let's find out what rights does an employee have in relation to his (her) creation.

\subsection{Intellectual non-property rights to a work-for-hire}

The legislation stipulates that personal non-property property rights in intellectual property law to an object created as the result of performance of an employment contract belong to the employee who created the object.

Personal non-property intellectual property rights are:

1) the right to recognize a person as the creator (author, performer, inventor, etc.) of the object of intellectual property rights.

2) the right to prevent any encroachment on the intellectual property right, capable of damaging the honor or reputation of the creator of the object of intellectual property rights.

3) other personal intangible intellectual property rights established by law.

Part 1, Article 429 of the Civil Code of Ukraine establishes that in the cases provided by the law, some personal non-property intellectual property rights to such object can belong to the legal or an individual, in which of for whom an employee works. However, such cases are not specified in the special Law "On Copyright and Related Rights".

The courts also insist on the inalienable nature of the non-property rights of the author of the work-for-hire. Thus, the Plenum of the Supreme Court of Ukraine established in its Resolution of June 4, 2010 no. 5 that if the work is created in the performance of the employment contract and within its validity, i. e. in the performance of the official duties or according to the assigned duty, then the personal intangible rights of the author of the work belong to the employee; they are inalienable.

In addition to the above mentioned non-property rights to work-forhire, the author also holds the following non-property rights related to the creation: 
1) to require the indication of his (her) name in connection with the use of the work, if it is practically possible;

2) to prohibit the indication of his (her) name in connection with the use of the work;

3) to choose a pseudonym in connection with the use of the work;

4) the inviolability of the work.

Article 6 bis of the Berne Convention (WIPO, 1971) provides that, independently of the author's economic rights, and even after the transfer of the said rights, the author shall have the right to claim authorship of the work and to object to any distortion, mutilation or other modification of, or other derogatory action in relation to, the said work, which would be prejudicial to his honor or reputation. These rights, recognized by the author, remain in force after his (her) death at least until the termination of property rights and are exercised by persons or institutions authorized to do so by the law of the country, in which protection is required.

\subsection{Intellectual property rights to a work-for-hire}

Intellectual property rights to an object created in connection with the performance of an employment contract shall belong jointly to the employee who created the object and to the legal or natural person, in which or for whom he (she) works, unless otherwise provided by the contract.

Intellectual property rights are:

1) the right to use the object of intellectual property rights;

2) the exclusive right to allow the use of the object of intellectual property rights;

3) the exclusive right to prevent the misuse of the object of intellectual property rights, including the prohibition of such use;

4) other property rights of intellectual property established by law.

At the same time, according to the Law of Ukraine "On Copyright and Related Rights", the exclusive property right to the official work belongs to the employer, unless otherwise provided by the employment contract and (or) civil contract between the author and the employer. Thus, there is a legal conflict, i.e. divergence between different regulations. In this case, the normative act of higher legal force is applied, i.e. the Civil Code of Ukraine. Therefore, we believe that the property rights belong to the author of the official work and the employer together, unless otherwise provided by the contract. 
However, joint use does not mean using work-for-hire equally, and, therefore, the disputes between an employee and employer may arise on this issue. To prevent such situations, it is necessary to enshrine the conditions, manner and procedure for the use of property rights to workfor-hire in the relevant employment or civil contract in detail.

The need to conclude a contract is indicated in the relevant case law. Thus, the Resolution of the Plenum of the Supreme Commercial Court of Ukraine of October 17, 2012 no. 12 states that such a contract can be: a) employment contract (indicating the provisions on the distribution of exclusive property rights to the work between the employer and the author or other creator, the amount of remuneration, a list of responsibilities for the creation of a particular work (works), the nature of the job, etc.); b) civil law contract, which can be concluded both before and after the creation of a work-for-hire.

If such an agreement is not concluded, the provisions of Art. 428 of the Civil Code of Ukraine are applied, which state that intellectual property rights that belong to several persons are exercised jointly. This means that each party uses the work-for-hire at its own discretion. To use the workfor-hire by the third parties, it is necessary to obtain permission both from the employer and the author (employee), because if they do not enter into an agreement agreeing on the terms, each party will not have the right to dispose of these rights without the consent of the other party.

At the same time, the rights to works, created beyond the employment contract or assigned duty, the order cannot be considered transferred to the employer or customer on the basis of law; for example, illustrations made by an employee to a work created in the performance of the official task will not be considered as works-for-hire if they are not provided for by such a task or employment contract with the employer. The boundaries of the job in case of dispute are determined taking into account both the content of the employment contract and other documents that determine the scope of duties of the employee (job descriptions, orders, directives, service notes, etc.) (Par. 35 of the Resolution no. 12).

\section{Calculation of the amount of royalties}

Let's consider another problematic issue in the legal relations under consideration, namely the amount of remuneration to the employee who is the author of the work-for-hire. Art. 16 of the Law of Ukraine "On Copyright and Related Rights" states that the author is entitled to royalties for the creation and use of a work-for-hire, the amount and payment of which are set by the employment contract and (or) civil law contract between the author and the employer. 
Some employers believe that remuneration for a job is already included in the salary, as its creation is provided by the employment contract (civil contract) and / or job description. However, this is not so, because according to Art. 1 of the Law of Ukraine "On wages and salaries" (1995), wages are remuneration, calculated, as a rule, in monetary terms, which the employer pays to the employee for the work performed by him (her) under the employment contract. The amount of salary depends on the complexity and conditions of work performed, professional and business qualities of the employee, the results of his (her) work and economic activity of the enterprise. Thus, the payment of wages to an employee is not the same as the payment of royalties for the work created, because wages are remuneration for the work performed depending on certain conditions, and royalties are all types of remuneration or compensation paid to the authors for the use of their works (Par. 25 of the Resolution no. 5).

The author of the work-for-hire has the right to receive two different rewards - for the creation of the work-for-hire and its use. Thus, according to Art. 445 of the Civil code of Ukraine the author has the right to a payment for the use of his (her) work. Art. 33 of the Law of Ukraine "On Copyright and Related Rights" states that the agreement on the transfer of rights to use works is concluded if the parties agree on all essential conditions (term of the contract, method of use of the work, the territory covered by the transferred right, the amount and the procedure for payment of royalties). Speaking of the right to use the work, the right to allow or prohibit the use of work-for-fire by other persons is omitted. Thus, this Law stipulates that only the agreement on the transfer of non-exclusive rights must be paid. According to Art. 31 of the Law of Ukraine "On Copyright and Related Rights", property rights transferred under a copyright agreement must be defined in it. Property rights, which are not specified in the copyright agreement as alienable, are considered not to be transferred. Consequently, there is a possibility of free transfer of all exclusive property rights in general (Potomkin, 2007)

This fact is also confirmed by the Instruction on Wage Statistics, approved by the Order of the State Statistics Committee of Ukraine of January 13 (2004) no. 5, which established that the Remuneration Fund includes:

a) a fee for full-time employees of editorial offices of newspapers, magazines, other mass media, publishing houses, art institutions and / or remuneration for their work, calculated at the rates of the author's remuneration set by given enterprise (Par. 2.1.3);

b) remuneration paid under the copyright agreement for the creation and use of works of science, literature and art (paragraph 3.14). 
The amount and the procedure for payment of royalties for official work is enshrined in the relevant contract, during the conclusion of which the parties should be guided by the provisions of the Resolution of the Cabinet of Ministers of Ukraine "On approval of minimum rates of royalties for the use of copyright and related rights" of January 18 (2003) no. 72, which states that the amount of remuneration cannot be less than the amount specified by the Resolution (this is usually determined in the form of a certain percentage or a clearly fixed amount) (Resolution of the Cabinet of Ministers of Ukraine "On approval of minimum rates of remuneration royalties for use objects of copyright and related rights" no. 72 from January $18,2003$.

In practice, there is usually a fixed amount of royalties set in the contract and linked to the scope of the work. This approach, on the one hand, is in the best interest of the performer: he is able to see a specific total amount in advance and can calculate the one he will receive as a result of his work. The specific amount specified in the contract allows the employer to plan the cost of the copyright object and the amount of profit he will receive from its use, as well as to avoid disputes with the employee about the amount to be paid for the transfer of copyright. The payment is recorded (cash disbursement order, payment order) with an indication that it is the royalties under a specific contract (Denisova, 2011).

At the same time, it should be noted that the Draft Law on Copyright and Related Rights is currently registered in the Verkhovna Rada at number 10143 of March 12, 2019, which provides different conditions for the payment of royalties for works-for-hire for the private and public sectors (Article 14 of the Draft Law). Thus, such a fee must be paid for any kind of use of the work-for-hire, except for computer programs and databases in private companies. Its amount and procedure for payment are determined by the employment contract or the agreement on the distribution of property rights to the work-for-hire, concluded between the author and the employer. The situation is somewhat different for the employees of public authorities: property rights to the created work-for-hire pass to the public authority without concluding a civil law contract and without payment of remuneration.

\section{Foreign experience}

The definition of "work-for-hire" first appeared in intellectual property law of the United States. This category includes not only works-for-hire (created by the employee within labor relations), but also 9 types of works created to order. Thus, the US Copyright Act (2016) defines a "work made for hire" in two parts: a) a work prepared by an employee within the scope of 
his or her employment or b) a work specially ordered or commissioned for use 1) as a contribution to a collective work, 2) as a part of a motion picture or other audiovisual work, 3) as a translation, 4) as a supplementary work, 5) as a compilation, 6) as an instructional text, 7) as a test, 8) as answer material for a test, or 9) as an atlas, if the parties expressly agree in a written instrument signed by them that the work shall be considered a work made for hire (Section 101 of the US Copyright Act).

However, despite a sufficiently detailed definition, it is difficult to establish whether a work belongs to the category of official or not. Therefore, the US courts first find out whether the work was prepared by an employee or an independent contractor. If an object is created by an employee while performing his work functions, it is considered to be work-for-hire. A work created by an independent contractor can be work-for-hire if: a) it falls within one of the nine categories of works listed in Par. 2 Article 101 cited above, and b) there is a written agreement between the parties stating that the object of intellectual property is exactly the work-for-hire.

In the United Kingdom the rights to work-for-hire created by an employee in the course of his (her) official (work) duties belong, as a general rule, to the employer. Like US courts, those in the UK consider a variety of factors to determine employment versus contract labor, including the presence of employee tax and benefits treatment, although the primary test is "whether the work undertaken forms an integral part of the business (Sutherland Asbill \& Brennan LLP, 2004).

Only an individual can be considered the author of work-for-hire according to French copyright law. He (she) owns all the rights associated with the created object of intellectual property, regardless of whether it is a work-for-hire or not. This rule applies to both the employee and the independent contractor. In resolving disputes related to the distribution of rights to works-for-hire, the French courts mainly use the relevant provisions of the Intellectual Property Code of France (1992), according to which the author of a work of the mind shall enjoy in that work, by the mere fact of its creation, an exclusive incorporeal property right which shall be enforceable against all persons. This right shall include attributes of an intellectual and moral nature as well as attributes of an economic nature. The existence or conclusion of a contract for hire or of service by the author of a work of the mind shall in no way derogate from the enjoyment of the right afforded by the first paragraph above (Art. L111-1 of the Intellectual Property Code of France). Thus, French law prohibits employers from claiming property right to works-for-hire, and the courts, as a general rule, refuse to recognize this right. However, there are some gaps in the laws that might be exploited by the employers.

The relevant legislative acts of Latvia, Moldova, Kazakhstan, Georgia, which regulate the distribution of rights to works-for-hire, provide that the 
Mykhailo Pokalchuk, Kateryna Sokh, Oksana Yalova, Liubov Zubkova y Iryna Borovska 354

Official work in Ukraine: characteristics of legal status and recurring problems

basis for the creation of a work-for-hire is the performance of official (work) functions or an assigned duty. In this case, the official duties of the employee are understood as his (her) functional responsibilities, fixed in employment contracts, job descriptions, which may lead to the creation of work-for-hire. Assigned duty, in its turn, is the task to the employee issued in writing that is directly related to the specifics of the enterprise or employer and can lead to the creation of work-for-hire.

As we can see, the concept of the official work provided in the Ukrainian legislation coincides with the definitions enshrined in the legislation of many other States in many respects. However, the issue of the distribution of rights to the work-for-hire between the employee and the employer is regulated differently by each country.

\section{Conclusion}

Thus, as a result of the study, we considered in detail the concept of the "work-for-hire", enshrined in the Law of Ukraine "On Copyright and Related Rights". The features of the work-for-hire were identified, which are at the same time the conditions for recognizing the work as work-forhire, which are: 1) the author is in an employment relationship with the employer on the basis of an employment contract; 2) the work must be created by the author in the performance of his (her) official duties (work functions); 3) the work must be created in accordance with the assigned duty or an employment contract between the author and the employer; 4) the creation of work-for-hire can be carried out both during working hours and after working hours, regardless of the place of its creation; 5) the object should be recognized as work-for-hire, if the employer provided its creator with the necessary financial, material or other assistance or otherwise contributed to it in the process of creating the specified object.

It was established that the personal non-property rights of the author to the work-for-hire belong to the employee and are inalienable. The property rights related to the creation of the work-for-hire work were listed. It was determined that property rights belong to the employee and the employer jointly, unless otherwise provided by an employment or civil contract. However, joint use does not mean using work-for-hire equally, which often leads to disputes between an employee and employer. To prevent such situations, it is necessary to enshrine the conditions, manner and procedure for the use of property rights to the work-for-hire in the relevant employment or civil contract in detail; the latter may be concluded both before and after the creation of the work-for-hire. 
The problematic issue in the legal relations under consideration is the determination of the amount of remuneration to the employee who is the author of the work-for-hire. Thus, the author is entitled to royalties for the creation and use of a work-for-hire work, the amount and procedure for payment of which are established by the contract. In practice, there is usually a fixed amount of royalties set in the contract and linked to the amount of work. In this case, the payment of wages to the employee is not the same as the royalties, although some employers believe otherwise. In addition, the author of the work-for-hire has the right to receive two different rewards for the creation of the work-for-hire and its use.

During the study of foreign experience on the issue under consideration, it was found that the concept of the official work provided in the Ukrainian legislation coincides with the definitions enshrined in the legislation of many other States in many respects. However, the issue of the distribution of rights to the work-for-hire between the employee and the employer is regulated differently by each country.

\section{Bibliographic References}

CABINET OF MINISTERS OF UKRAINE. 2003. Resolution "On approval of minimum rates of royalties for the use of copyright and related rights" of January 18, 2003 no. 72. Available online. In: http://www. zakon2. rada.gov.ua/laws/show/72-2003-\%Do\% BF. Date of consultation: 15/03/2020.

DENISOVA, Rymma. 2011. "Copyright on works-for-hire" In Problems of Legality. No. 115, pp. $54-59$.

DRAFT LAW OF UKRAINE. 2019. On Copyright and Related Rights of March 12, 2019 no. 10143. Available online. In: http://w1.c1.rada.gov.ua/pls/ zweb2/webproc4_1?pf3511=65661. Date of consultation: 15/03/2020.

GARON, John; ZIFF, Elaine. 2011. "The Work Made for Hire Doctrine Revisited: Startup and Technology Employees and the Use of Contracts in a Hiring Relationship" In: Minnesota Journal of Law Science \& Technology, Vol. 12, No. 2. Available online. In: https://scholarship.law.umn.edu/mjlst/ vol12/iss2/5. Date of consultation: 20/03/2020.

HARRIS, Matthew. 1990. "Copyright, Computer Software, and Work Made for Hire" In: Michigan Law Review, Vol. 89, No. 3, pp. 661-701. Available online. In: https://repository.law.umich.edu/mlr/vol89/iss3/7. Date of consultation: 20/03/2020. 
Mykhailo Pokalchuk, Kateryna Sokh, Oksana Yalova, Liubov Zubkova y Iryna Borovska

356

Official work in Ukraine: characteristics of legal status and recurring problems

KULBASHNA, Olena. 2013. "Works-for-hire of intellectual property law: the questions of theory" In: Theory and Practice of Intellectual Property. No. 6, pp. 57-61.

LAW OF FRANCE. 1992. Intellectual Property Code of 1 July no. 199292-597. Available online. In: https://www.legifrance.gouv.fr/affichCode.do?c idTexte=LEGITEXToooo06069414\&dateTexte=20080129. Date of consultation: 15/03/2020.

LAW OF UKRAINE. 1993. On Copyright and Related Rights of December 23, 1993 no. 3792-XII. Available online. In: https://zakon.rada.gov.ua/ laws/show/435-15. Date of consultation: 15/03/2020.

LAW OF UKRAINE. 1994. On protection of rights to inventions and utility models" of December 15, 1993 no. 3687-XII. Available online. In: https:// zakon.rada.gov.ua/laws/show/3687-12\#Text. Date of consultation: 18/03/2020.

LAW OF UKRAINE. 1995. On wages and salaries of March 24, 1995 no. 108/95VR. Available online. In: https://zakon.rada.gov.ua/laws/show/108/95\%Do\%B2\%D1\%80\#Text. Date of consultation: 17/03/2020.

LAW OF UKRAINE. 2003. Civil Code of Ukraine of January 16, 2003 no. 435IV. Available online. In: https://zakon.rada.gov.ua/laws/show/435-15. Date of consultation: 15/03/2020.

POTOMKIN, Andryi. 2007. "Royalties" In: Legal Bulletin of Ukraine. No. 52. Available online. In: https://www.zakon-i-normativ.info/index.php/ component/lica/ ? href $=0$ \& view $=$ text $\&$ base $=1 \&$ id $=328405 \&$ menu $=460325$. Date of consultation: 17/03/2020.

SOLOVIOVA, Valeriia. 2008. "The objects of intellectual property law and acquisition of intellectual property rights by the employer and employee" In: Current issues of civil and commercial law. No. 4, pp. 30-45.

STATE STATISTICS COMMITTEE OF UKRAINE. 2004. Instruction on Wage Statistics, adopted by the Order of January 13, 2004 no. 5. Available online. In: http://mis.ueplac.kiev.ua/ua/tools/addressbook/. Date of consultation: 17/03/2020.

SUPREME COMMERCIAL COURT OF UKRAINE. 2012. Resolution on some issues of dispute resolution practice related to the protection of intellectual property rights of October 17, 2012 no. 12. Available online. In: https://zakon.rada.gov.ua/laws/show/voo1260o-12\#Text. Date of consultation: $18 / 03 / 2020$. 
SUPREMECOURTOF UKRAINE. 2010. Resolution on the application of norms of the legislation in cases of protection of copyright and related rights of June 04, 2010 no. 5. Available online. In: https://zakon.rada.gov.ua/ laws/show/vooo5700-10\#Text. Date of consultation: 18/03/2020.

SUTHERLAND ASBILL \& BRENNAN LLP. 2004. Analysis of International Work-for-Hire Laws. Available online. In: https://us.evershedssutherland.com/portalresource/lookup/poid/Z1tOl9NPluKPtDNIqL MRV56Pab6TfzcRXncKbDtRrgtObDdEuS3Dro!/fileUpload.name=/ WorkforHireLaws.pdf. Date of consultation: 20/03/2020.

US COPYRIGHT OFFICE. 2016. Copyright Law of the United States and Related Laws Contained in Title 17 of the United States Code. Available online. In: https://www.copyright.gov/title17/title17. Pdf. Date of consultation: 17/03/2020.

WIPO. 1971. Berne Convention for the Protection of Literary and Artistic Works, adopted by the Paris Act of July 24, 1971, as amended on September 28, 1979. Available online. In: https://wipolex.wipo.int/en/text/283693. Date of consultation: 18/03/2020. 


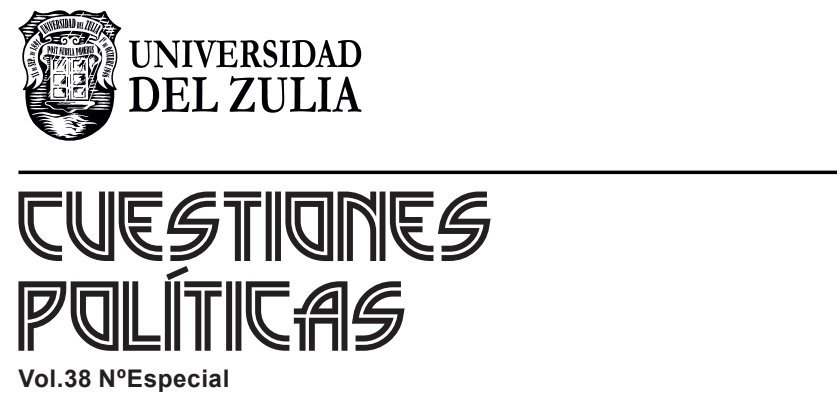

www.luz.edu.ve 